\title{
SNP Association in the Leptin Gene and Beef Quality Traits in Indigenous Sudanese Baggara Cattle
}

\author{
Romaz M.A. Omer ${ }^{1}$, Mai A. Masri², Lutfi M.A. Musa ${ }^{3}$, Ikhlas A. Nour ${ }^{1,6}$, Mitsuru Tsubo ${ }^{4}$, \\ Faisal M. El-Hag, ${ }^{4,5}{ }^{*}$, Ahmed D.A. Biraima ${ }^{6}$, Khaleel I.Z. Jawasreh ${ }^{7}$, Yasunori Kurosaki ${ }^{4}$ and \\ Mohammed-Khair A. Ahmed ${ }^{3}$ \\ ${ }^{1}$ Institute for Studies and Promotion of Animal Exports, University of Khartoum, Sudan \\ ${ }^{2}$ Department of Zoology, Faculty of Science, University of Khartoum, Sudan \\ ${ }^{3}$ Department of Genetics and Animal Breeding, Faculty of Animal Production, University of Khartoum, Sudan \\ ${ }^{4}$ Arid Land Research Centre (ALRC), Tottori University, 1390 Hamasaka, Tottori 680-0001, Japan \\ ${ }^{5}$ Agricultural Research Corporation (ARC), Sudan \\ ${ }^{6}$ Department of meat Production, Faculty of Animal Production, University of Khartoum, Sudan \\ ${ }^{7}$ Department of Animal Productions, Faculty of Agriculture, Jordan University of Science and Technology, Jordan \\ Email: faisalelhag@hotmail.com
}

\begin{abstract}
The present study was conducted on 112 Sudanese Baggara bulls (Nyalawi and Mesairi strains) from two separate locations in Darfur and Kordofan, Sudan, raised under dryland farming conditions. A single nucleotide polymorphism (C/T) Arg25Cys in exon 2 of the bovine leptin gene (NC_032653.1) was studied and the association of leptin genotypes with meat quality attributes was evaluated for these two Sudanese Baggara cattle strains which comprise the mainstay of Sudan export and local beef trade. The accuracy of genotyping was checked through PCR-RFLP technique followed by DNA sequencing and analyzed using BioEdit, MEGA6 and project Hope softwares. The genotype frequencies for CC, CT and TT genotypes in Nyalawi strain were 37.5, 39.3 and 23.2\%, respectively, whereas the respective genotypic frequencies for Mesairi strain were 46.4, 28.6 and 25\%. Significant differences $(\mathrm{P}<0.05)$ were found in hot carcass weight, dressing percentage, Myofibril fragmentation index (MFI), water holding capacity (WHC), cooking loss, moisture and fat between the two Baggara cattle strains. Association between the $\mathrm{C}>\mathrm{T}$ SNP at the leptin gene and carcass weight, dressing and fat percentages was significant $(\mathrm{P}<0.05)$. It was concluded that Leptin gene polymorphisms contributed to the observed meat quality differences among these Sudanese cattle strains. This will allow for the use of molecular information in future selection of beef cattle in Sudan. The possible value of the leptin gene and its polymorphisms have been elucidated for the first time in Baggara cattle.
\end{abstract}

Keywords: Baggara cattle strains; dryland; Leptin genotypes; meat quality traits.

\section{Introduction}

Livestock production is the main income generating activity for Sudanese rural population. The country has a large livestock population that includes 41.65 million cattle (Wilson, 2018) largely of zebu type. The cattle of Sudan are classified into different ecotypes according to geographic location or tribal ownership. Baggara cattle (Bos indicus) represent the mainstay of Sudan's beef exports and are very important for the livelihoods of a significant proportion of the population. Nyalawi and Mesairi are two important Baggara cattle strains (Omer et al., 2018), that have different characteristic morphologies (Alsiddig et al., 2010). Omer et al. (2018) reported that these two Baggara cattle strains are both considered as main producers of beef for Sudan local consumption and export to neighboring countries.

Genetic improvement of these cattle using traditional breeding methods is difficult because they are mainly raised under dryland pastoral systems of management. However, formal selection has rarely been implemented in local breeds (Biscarini et al., 2015). The use of molecular techniques can assist in overcoming some of the problems created by the traditional system of management. The application of molecular tools creates many opportunities for beef production through increased genetic progress 
(Mrode et al., 2019) and the possibility of including new economically important traits in selection indices (Miller, 2010). Molecular selection can then offer the possibility of selecting animals at a younger age thereby reducing generation interval and testing more animals allowing increased selection intensity (Koopaee and Koshkoiyeh, 2014).

Leptin gene which encodes a $16 \mathrm{kDa}$ peptide hormone (Mohamed et al., 2020; Omer et al., 2018) is the product of the obese gene and is synthesized and secreted predominantly by white adipocytes (MacDougald et al., 1995) in adipose tissue (Ramos-Lobo and Donato Jr., 2017). Shin and Chung (2007) related that to the feedback system that regulates long term body fat weight and composition. Therefore, the leptin gene could be an excellent candidate gene controlling fat deposition, carcass traits and meat quality in beef cattle (Shin and Chung, 2007). The principal site of leptin production is adipocytes (Geary et al., 2003), and as adipocytes increase in mass, peripheral concentrations of leptin increase (Ramos-Lobo and Donato Jr., 2017). Adipocyte size may influence leptin synthesis and secretion because larger adipocytes contained more leptin mRNA (Harris, 2014). The proportion of fat in the carcass, especially intramuscular fat (marbling) plays an important role in the sensory characteristics of meat (Fergusson, 2004). Since the discovery of the leptin gene (Zhang et al., 1994) and of the leptin receptor gene (Tartaglia, 1997), many studies (Nkrumah et al., 2005; da Silva et al. 2012; Souza et al., 2014) have been published on polymorphisms in both genes in several species. The SNP (Arg25Cys) of leptin gene was found to be associated with fat and muscle traits in crosses of Angus $\mathrm{x}$ Hereford, Simmental x Hereford, and Tarentaise x Hereford (Bierman et al., 2004), and that the $\mathrm{T}$ allele was found to be associated with progressive increases in backfat thickness in Western Canadian feedlot cattle (Woronuk et al., 2012).

The aims of this study were to estimate the allele and genotype frequencies of the Arg25Cys SNP in the Leptin gene and to test for the association between this SNP and meat quality traits of Sudanese Nyalawi and Mesairi Baggara cattle.

\section{Materials and Methods}

Ethical approval: Animals Use in Research was according to the committee of the University of Khartoum regulations. The guidelines and regulations set out by the Sudan Veterinary Council were strictly followed during animal handling and sampling.

All experimental protocols used are approved by the University of Khartoum and in accordance with the University of Khartoum Laboratory Authority guidelines.

\subsection{Animals and Sampling}

One hundred and twelve bulls of an average age of 4-5 years representing Mesairi and Nyalawi strains (Fifty-six bulls each) were used. The animals were originally raised under dryland farming conditions in western Sudan (Kordofan and Darfur), brought to Khartoum, fed, and finished in a traditional feedlot for three months. The ration composed of $8 \%$ groundnut cakes, $10 \%$ cotton seed cake, and $40 \%$ sorghum grains. Roughages were sorghum straws 20\%, wheat bran $20 \%$ and $1 \%$ from each of limestone and common salt were added.

Slaughter weights $(\mathrm{kg})$ were determined at the slaughterhouse using the cattle weighing tape (Weigh band). Immediately after dressing each carcass was divided into four quarters then each of the two-fore and two-hind quarters were weighed together using a digital balance of $500 \mathrm{~kg}$ capacity and added up to give the complete hot carcass weight. A total of 112 meat samples were cut from the Longissmus thoracis muscles (left half of the carcass) between the $11^{\text {th }}$ and the $12^{\text {th }}$ ribs as described by Shafey et al. (2020), within one-hour post-slaughter under septic conditions. External fat was trimmed off and each individual muscle was labeled and transferred in ice box and kept at $-18^{\circ} \mathrm{C}$ for meat quality determinations.

Water holding capacity (WHC) was determined using rapid filter paper method according to Warner (2014). Myofibril fragmentation index (MFI) was determined according to the methods described by Hopkins et al. (2000). Cooking loss was determined as the difference in weight of samples before and after cooking and was expressed as a percentage of the weight before cooking (Bouton et al., 1978). The 
determination of total moisture, ash, total protein, and fat (ether extract) were performed according to AOAC (2016) methods.

Blood samples (5 ml each) were taken from the jugular vein of each Baggara bulls using vacutainers containing EDTA as an anticoagulant and were held at $4^{\circ} \mathrm{C}$ pending analysis. Genomic analyses were done at the Centre of Excellence, Genetic and Molecular Biology Laboratory at the Department of Zoology, Faculty of Science, University of Khartoum.

\subsection{Genomic DNA Extraction}

DNA was extracted following conventional methods (Miller et al., 1988; Omer et al., 2018). A thorough description of procedures and methods followed was given in Omer et al. (2018).

\subsection{Genotyping of the Leptin Gene}

The leptin gene locus was analyzed targeting a 94bp fragment covering the sequence containing the targeted SNP. The amplification procedure of the targeted leptin sequence proposed by a previous study (Fiona et al., 2002) was conducted using the following primers:

\section{F: ATGCGCTGTGGACCCCTGTAT and $R$ : TGGTGTCATCCTGGACCTTCC.}

The resulting PCR fragments were digested using the restriction enzyme endonuclease Kpn21 (T/CCGGA). The reactions were performed using a G-Storm Thermal Cycler (Gene Technologies Ltd, Braintree, Esses, CM77 6tz, UK) (Shafey et al., 2020). Each PCR reaction was made in a $25 \mu \mathrm{L}$ volume containing $1 \mathrm{x}$ PCR buffer (10mM Tris- $\mathrm{HCl}, 50 \mathrm{mM} \mathrm{KCl}) ; 1 \mu$ dNTPs $(10 \mathrm{mM}), 1.25 \mu \mathrm{L} \mathrm{MgCl2}(50$ $\mathrm{mM}) .1 \mathrm{U}$ of Taq polymerase, $1 \mu \mathrm{L}$ of each primer $(10 \mu \mathrm{M})$ and $100-200 \mathrm{ng} / \mu \mathrm{L}$ DNA then the volume was completed to 25 using $\mathrm{ddH}_{2} \mathrm{O}$. PCR cycles included: initial denaturation at $94^{\circ} \mathrm{C}$ for 2 min followed by 30 cycles of denaturation step at $94^{\circ} \mathrm{C}$ for $45 \mathrm{sec}$, annealing at $59^{\circ} \mathrm{C}$ for $45 \mathrm{sec}$, extension at $72^{\circ} \mathrm{C}$ for $55 \mathrm{sec}$ and a last cycle of extension at $72^{\circ} \mathrm{C}$ for 5 min (Shafey et al., 2020). The PCR product was kept at $4^{\circ} \mathrm{C}$ until collected (Shafey et al., 2020). After electrophoresis, the gel PCR products were visualized with a gel documentation UVITEC machine, UK.

\subsection{Sequence Analysis, Alignment Procedures and Functional Analysis}

One PCR product of each different genotype of the Leptin genes was sequenced commercially (Omer et al.,2018) to confirm the detected genotypes using ABI 3730xl DNA analyzers, with Big Dye Terminator v3.1. PCR products were purified prior to sequencing and were sequenced in both directions (Omer et al., 2018). The resulting sequences were aligned and compared using MEGA program in addition to selected available GenBank sequences as described by Omer et al. (2018).

The number of base substitutions per site between sequences and standard error estimate (s) analyses were conducted (Omer et al., 2018) using the Tajima-Nei model (Tajima and Nei, 1984). Molecular evolutionary genetic analyses were conducted using MEGA6 (Tamura et al., 2013). The gene and genotype frequencies were calculated using Falconer and Mackay (1996) method. Protein structure analysis of mutations was conducted using project Hope and Chimera softwares.

\subsection{Statistical Analyses}

The data were statistically analyzed using mixed procedure of SAS (Meyers et al., 2009). Animals were assigned as random effect, while the other factors (breed and genotype and their interactions) were inserted as fixed effects. Least square means were used for testing the differences between means via SAS software programs (Meyers et al., 2009). The expected genotype frequencies were calculated using the Hardy-Weinberg law. Chi square $(\chi 2)$ test was used for testing the association between the genotypes and levels of traits. 


\section{Results}

\subsection{Genotyping of Leptin Gene}

The digestion of the $94 \mathrm{bp}$ (Figure 1) PCR product with the Kpn21 endonuclease enzyme produced three restriction patterns; two fragments assigned as the homozygote wild type genotype (CC) (75 and 19bp), heterozygote genotype (CT) produced three fragments (94, 75 and 19bp), while the uncut product (94 bp) was assigned as the homozygote mutant type (TT) (Figure 2). The sequencing results of the three genotypes confirmed genotyping assay (Figure 3). Table (1) shows that the genotype frequencies of CC, CT and TT in Nyalawi strain were 37.5, 39.3 and 3.2\%, respectively, compared with respective genotypic values of 46.4, 28.6 and $25 \%$ in Mesairi strain. This indicated that the Mesairi subtype was not at Hardy-Weinberg equilibrium $(\chi 2=5.862)$, while the Nyalawi subtype was at HWE $(\chi 2=2.388)$.

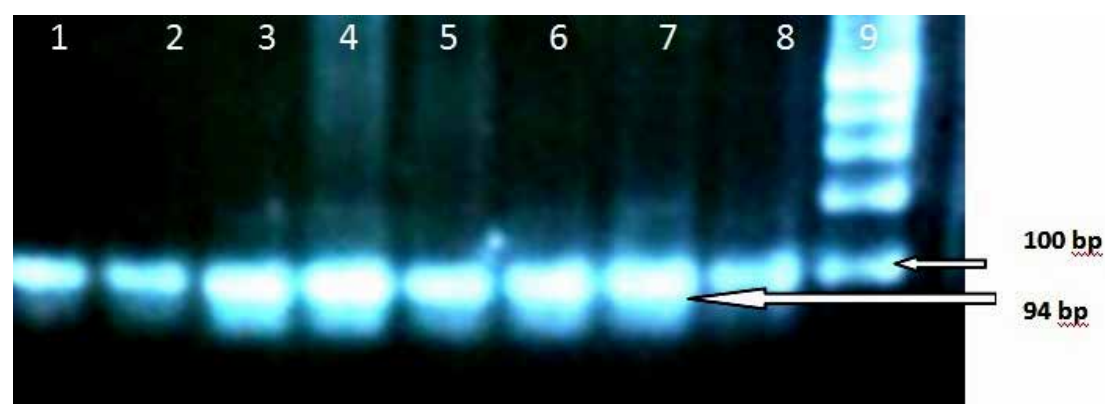

Figure 1. Agarose gel electrophoresis (2\%) displaying PCR amplification of a $94 \mathrm{bp}$ of exon2 of the Baggara (Leptin) Lanes:1-8 PCR products of samples. Lane9: 100 bp DNA Ladder

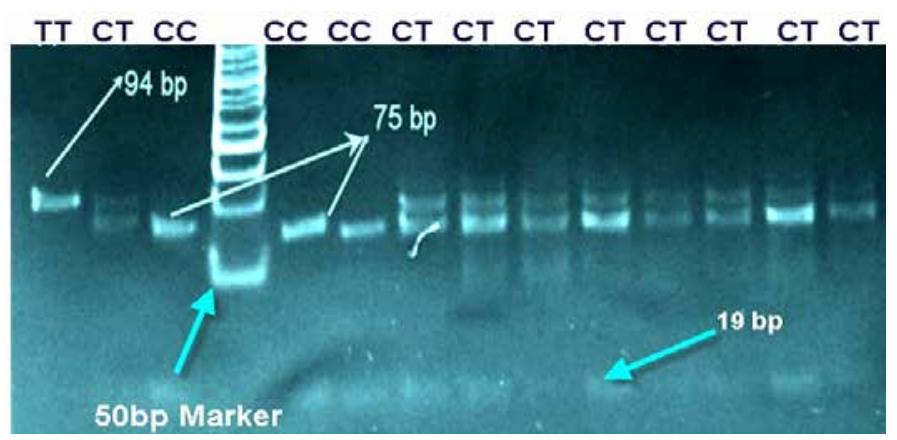

Figure 2. Agarose gel (2\%) electrophoresis displaying a kpn21 restriction digest of the amplified portion of Baggara Leptin gene 
C T TACG T G GAG GC T G T G C C CATC C G CAAG G T C CA G G AT G

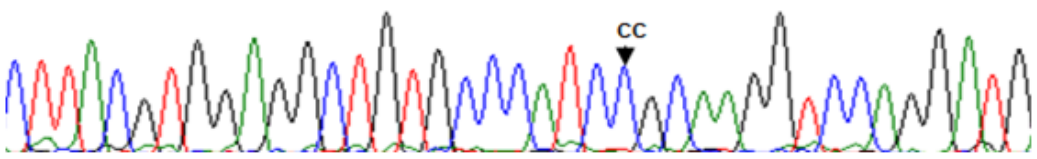

C T TACG T G G AG GC T G T G C C CATC T G CAAG G T C A G G T G

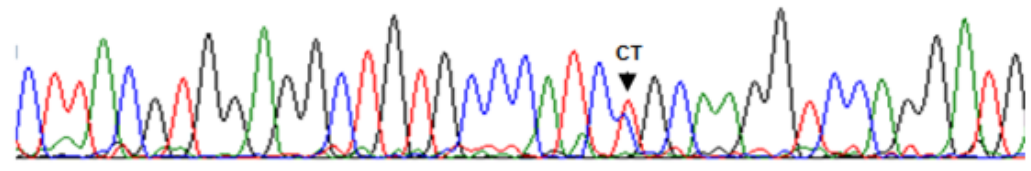

C T TACG T G GAG GC TGT G C C CA T C T G CAAG G T C CA G G AT G

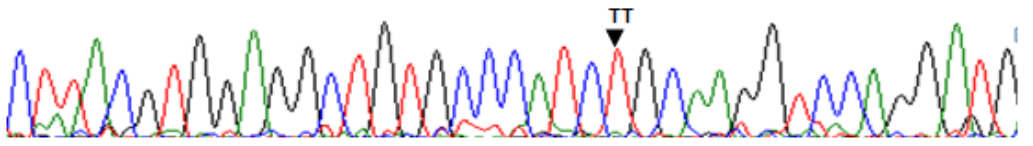

Figure 3. The chromatogram of the sequenced PCR product of Leptin gene confirming the three genotypes: homozygote (CC and TT) and the heterozygote (CT) genotypes

Table 1. Genotypic and allelic frequencies, $\chi 2$ test values and diversity parameters for (Arg25Cys) substitution of Leptin gene

\begin{tabular}{llllllll}
\hline Baggara subtype (number) & Genotype & No. & GF & Allele & AF & $\chi 2 / H W E$ & He \\
\hline Nyalawi (56) & C/C (Arg/Arg) & 21 & 0.375 & C & 0.5714 & 2.3883 & 0.4 \\
& C/T (Arg/cys) & 22 & 0.393 & T & 0.4286 & & \\
T/T (cys/cys) & 13 & 0.232 & & & & \\
Mesairi (56) & C/C (Arg/Arg) & 26 & 0.464 & $\mathrm{C}$ & 0.6071 & 5.8617 & 0.36 \\
& $\mathrm{C} / \mathrm{T}$ (Arg/cys) & 16 & 0.286 & $\mathrm{~T}$ & 0.3928 & & \\
$\mathrm{~T} / \mathrm{T}$ (cys/cys) & 14 & 0.250 & & & & \\
\hline
\end{tabular}

*GF: Genotype Frequency, AF: Allelic Frequency, $\chi 2$ /HWE: Hardy-Weinberg equilibrium $\chi 2$ value, HardyWeinberg equilibrium $(\mathrm{P}>0.05)$, He: Gene heterozygosity.

\subsection{Bovine Leptin Gene Sequencing and Alignment}

The obtained leptin sequence of Baggara strains was compared with the GenBank leptin gene sequence (NC_032653.1) and were also aligned with other available leptin gene sequences in the GenBank using MEGA software programme (Figure 4). The available sequences were Bos taurus (AJ236854.1) and Colombian Creole Cattle (JQ711179.1), Bos indicus: Nelore breed (EU921636.1) and (FJ626855.1), Brahman (EU921635.1), Indonesian cattle (EU921637.1), crossbred (Karan Fries) cows (GU907777.1), (GU907776.1) and Sahiwal cattle (EU313203.1). The missense mutation in the Leptin gene (C>T) was found in the two strains of Baggara cattle. Similar results were found in Bos taurus according to GenBank (AJ236854.1 and JQ711179.1,) and in Bos indicus according to GenBank (FJ626855.1, GU907777.1). 


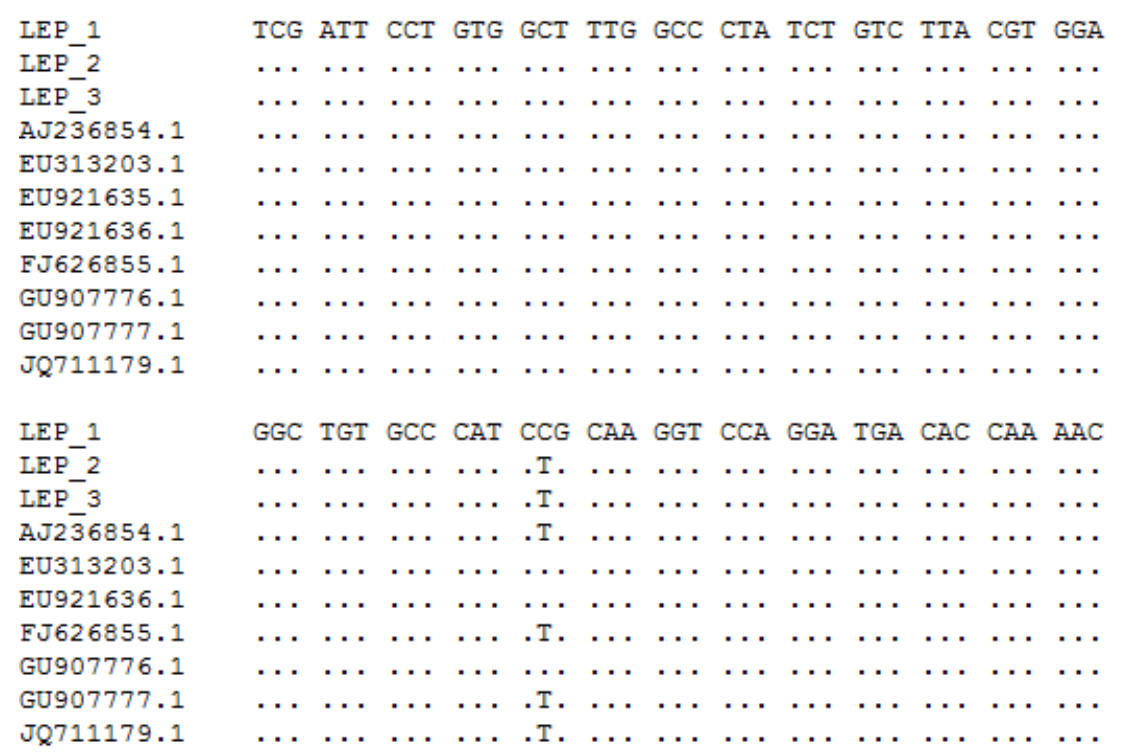

Figure 4. Aligned sequences of the Leptin (exon2) sequences of Baggara cattle and available GenBank sequences. The alignment was performed using the Clustal W2 sequence alignment

\subsection{Functional Analysis}

Project Hope (http://www.cmbi.ru.nl/hope/home), a fully automatic programme that analyzes the structural and functional effects of point mutations, reported that the original wild-type residue and newly introduced mutant residue differ in the properties. The wild-type residue (Arg) charge was positive, the mutant residue (Cys) charge is neutral, the charge of the wild-type residue will be lost, this can cause loss of interactions with other molecules or residues. The mutant residue is smaller than the wild-type residue, which might lead to loss of interactions. The mutation introduces a more hydrophobic residue at this position; this can result in loss of hydrogen bonds and/or disturb correct folding (Figure 5).

A

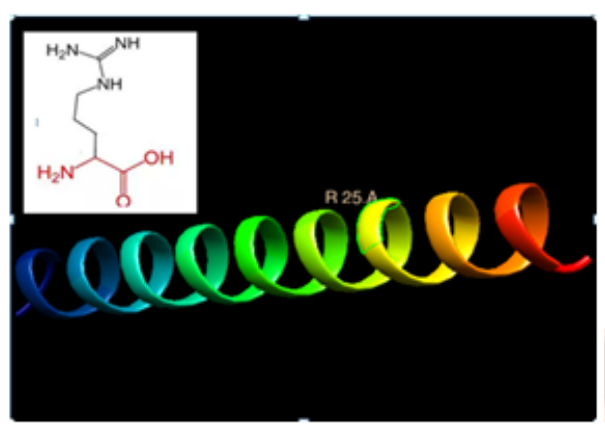

B

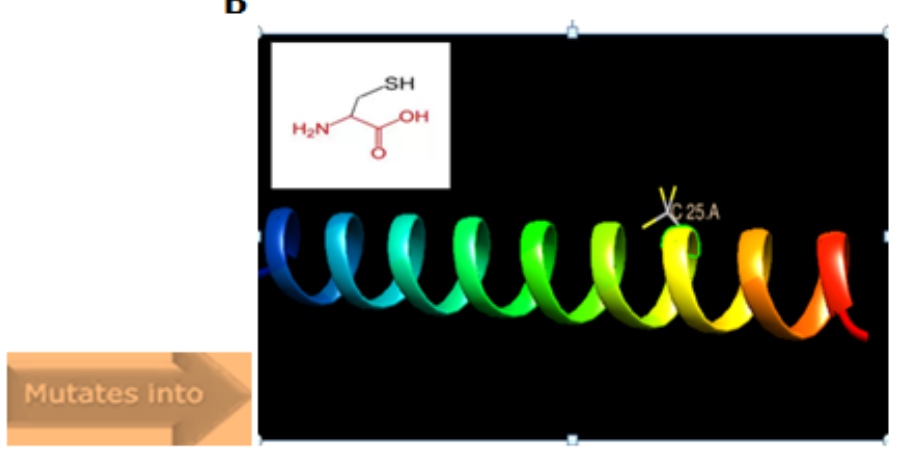

Figure 5. The schematic structure of the original (up) and the mutant (down) secondary structures that were drawn using Chimera software version 1.8. A and B. the amino acids were drawn by project Hope software, the backbone, which is the same for each amino acid, is colored red. The side chain, which is different for the two amino acids, is colored black.

\subsection{Leptin Gene Association with Meat Traits}

The Chi-square test showed a significant $(\mathrm{P}<0.05)$ association between the leptin genotypes on one hand, and the breed subtypes, hot carcass, dressing percentage and fat percent of Baggara strains, on the 
other hand. The association between leptin genotypes and MFI was close to significance $(\mathrm{P}=0.07)$, while the association with live weight, water holding capacity, cooking loss and meat chemical composition traits was not significant (Table 2).

Table 2. Chi-Square test of association between leptin genotypes and breed strains, live weight, meat quality traits of Baggara bulls.

\begin{tabular}{llll}
\hline Trait & Person's $\chi^{2}$ & D.F. & Significance \\
\hline Breed strains & 7.223 & 2 & 0.027 \\
Live weight $(\mathrm{kg})$ & 4.717 & 2 & 0.095 \\
Hot carcass $(\mathrm{kg})$ & 7.788 & 2 & 0.20 \\
Dressing percentage & 9.099 & 2 & 0.011 \\
myofibril fragmentation index (MFI) & 5.266 & 2 & 0.072 \\
Water holding capacity (WHC) & 2.150 & 2 & 0.341 \\
Cooking loss & 0.521 & 2 & 0.771 \\
Moisture & 2.711 & 2 & 0.258 \\
Protein & 2.075 & 2 & 0.354 \\
Fat & 5.698 & 2 & 0.058 \\
Ash & 0.192 & 2 & 0.909 \\
\hline
\end{tabular}

The analysis of variance showed that differences between breed strains in hot carcass weight, dressing percentage MFI, WHC, cooking loss, moisture and fat were significant $(\mathrm{P}<0.05)$, while the difference was not significant $(\mathrm{P}>0.05)$ with regard to live weight, ash and protein. The results revealed that the Baggara breed strains of Nyalawi and Mesairi are significantly different in the meat quality attributes (Table 3).

The least square means show that, the Nyalawi gave significantly low muscle moisture (74.3\%) and cooking loss $(36.4 \%)$ and significantly higher live weight $(453.93 \mathrm{~kg})$, hot carcass $(332.1 \mathrm{~kg})$, dressing

Table 3. Least squares means and standard errors of the effect of breed subtypes and leptin genotypes on carcass characteristics and meat quality.

\begin{tabular}{|c|c|c|c|c|c|c|}
\hline Item & Live weight $( \pm \mathrm{SE})$ & Hot carcass $( \pm \mathrm{SE})$ & Dressing $\%( \pm \mathrm{SE})$ & MFI $( \pm$ SE $)$ & WHC $( \pm \mathrm{SE})$ & Cooking loss $( \pm \mathrm{SE})$ \\
\hline \multicolumn{7}{|c|}{ Breed subtypes: } \\
\hline Nyalawi & $453.93 \pm 5.085 \mathrm{a}$ & $332.05 \pm 3.269 \mathrm{a}$ & $51.138 \pm 0.353 \mathrm{a}$ & $32.056 \pm 0.577 \mathrm{a}$ & $2.519 \pm 0.089 \mathrm{~b}$ & $36.468 \pm 0.505 b$ \\
\hline Mesairi & $444.49 \pm 4.422 \mathrm{a}$ & $207.83 \pm 2.819 \mathrm{~b}$ & $47.294 \pm 0.302 \mathrm{~b}$ & $26.593 \pm 0.518 \mathrm{~b}$ & $3.367 \pm 0.078 \mathrm{a}$ & $39.689 \pm 0.441 \mathrm{a}$ \\
\hline \multicolumn{7}{|c|}{ Leptin genotype: } \\
\hline $\mathrm{CC}$ & $451.86 \pm 5.406 \mathrm{a}$ & $219.19 \pm 3.451 \mathrm{a}$ & $49.0169 \pm 0.356 \mathrm{a}$ & $29.353 \pm 0.613 \mathrm{a}$ & $2.809 \pm 0.095 b$ & $37.322 \pm 0.538 \mathrm{a}$ \\
\hline $\mathrm{CT}$ & $453.92 \pm 5.649 \mathrm{a}$ & $224.84 \pm 3.603 \mathrm{a}$ & $49.5262 \pm 0.387 \mathrm{a}$ & $29.493 \pm 0.166 \mathrm{a}$ & $3.151 \pm 0.099 \mathrm{a}$ & $38.687 \pm 0.563 \mathrm{a}$ \\
\hline $\mathrm{TT}$ & $441.84 \pm 6.326 \mathrm{a}$ & $215.79 \pm 4.0064 \mathrm{a}$ & $49.1057 \pm 0.407 \mathrm{a}$ & $29.493 \pm 0.733 \mathrm{a}$ & $2.867 \pm 0.111 \mathrm{ab}$ & $38.226 \pm 0.631 \mathrm{a}$ \\
\hline
\end{tabular}

MFI: Myofibril Fragmentation Index;

a,b, Means in the same column under the same item with no letter in common are significantly different $(\mathrm{P}<0.05)$

Table 4. Least squares means and standard errors of the effect of breed subtypes and leptin genotype on meat chemical composition.

\begin{tabular}{lcccc}
\hline Item & Moisture $( \pm \mathrm{SE})$ & Protein $( \pm \mathrm{SE})$ & Fat $( \pm \mathrm{SE})$ & Ash $( \pm \mathrm{SE})$ \\
\hline Breed subtype: & & & & \\
Nyalawi & $74.288 \pm 0.149 \mathrm{~b}$ & $19.982 \pm 0.366 \mathrm{a}$ & $1.928 \pm 0.078 \mathrm{a}$ & $1.106 \pm 0.031 \mathrm{a}$ \\
Mesairi & $74.946 \pm 0.134 \mathrm{a}$ & $20.536 \pm 0.315 \mathrm{a}$ & $1.660 \pm 0.069 \mathrm{~b}$ & $1.107 \pm 0.027 \mathrm{a}$ \\
\hline Leptin genotype: & & & & \\
CC & $74.608 \pm 0.158 \mathrm{a}$ & $20.262 \pm 0.384 \mathrm{a}$ & $1.742 \pm 0.083 \mathrm{a}$ & $1.094 \pm 0.033 \mathrm{a}$ \\
CT & $74.555 \pm 0.171 \mathrm{a}$ & $19.942 \pm 0.403 \mathrm{a}$ & $1.870 \pm 0.088 \mathrm{a}$ & $1.117 \pm 0.035 \mathrm{a}$ \\
TT & $74.689 \pm 0.189 \mathrm{a}$ & $20.572 \pm 0.445 \mathrm{a}$ & $1.771 \pm 0.098 \mathrm{a}$ & $1.108 \pm 0.039 \mathrm{a}$ \\
\hline
\end{tabular}

a,b, Means in the same column under the same item with different letters are significantly different $(\mathrm{P}<0.05)$ 
percentage $(51 \%)$, fat (1.9\%), water holding capacity $(2.6 \%)$ and myofibril fragmentation index $(32.1 \%)$ than the Mesairi subtype. The effects of leptin genotypes on carcass characteristics, nutritional composition and meat quality were not significant in all studied traits except on WHC $(\mathrm{P}<0.05)($ Table 4). However, the CT genotype had a much higher average live weight, and hot carcass weight followed by CC genotype, while the TT genotype in both stains had a lower mean in these traits, but the difference was not statistically significant.

\section{Discussion}

Two important Sudanese Baggara cattle strains (Nyalawi and Mesairi) were targeted for genotyping in an important candidate gene in beef cattle production. The results of genotyping of the SNP (Arg25Cys) in exon 2 indicated the existence of this mutation in the two Baggara subtypes. This result is in disagreement with a previous research (Choudhary et al., 2005) which suggested that Kpn2I mutation is a source of genetic difference between Bos indicus and Bos taurus cattle (da Silva et al., 2012), because it was only detected in taurine cattle (da Silva et al., 2012). The researchers suggested that it occurred recently in evolution after the divergence of taurine and indicine cattle. Similar results were found in Bos taurus according to GenBank (AJ236854.1) and in Colombian Creole Cattle (JQ711179.1,) and in Bos indicus according to GenBank (in Nelore breed FJ626855.1 and crossbred Karan Fries cows GU907777.1).

The analysis of the structural and functional effects of point mutations (Venselaar et al., 2010; Awan et al., 2017) reported that, the original wild-type residue (Arg) and the mutated residue (Cys) are different in their properties (Awan et al., 2017), each amino acid has its own specific size, charge, and hydrophobicity-value (Kaur et al. 2016).

The Chi-square $(\chi 2)$ test indicated that the Mesairi strain was not in Hardy-Weinberg equilibrium $(\chi 2$ $=5.862)$, while the Nyalawi strain was in $\operatorname{HWE}(\chi 2=2.388)$ with regard to this locus. The deviation from equilibrium in Mesairi strain is probably a result of exchange of alleles between populations, selective pressure for or against any of the genotypes and population subdivision.

In this study there was significant $(\mathrm{P}<0.05)$ association between the leptin genotypes and the Baggara subtypes, hot carcass weight, dressing percentage and fat percent. The genotype TT in both subtypes had lower mean live weight and hot carcass weight compared to the other two genotypes (CC and CT). Genotype CT had a much higher mean in both traits. This is in agreement with Woronuk et al., (2012) who evaluated this SNP in Western Canadian feedlot cattle. These authors mentioned that homozygous animals for the $\mathrm{C}$ allele were not different from the heterozygous (CT) genotype with respect to live body weight, while both CC and CT genotypes were significantly heavier than animals with the TT genotype. In fact, the genotype CT had the highest mean weight followed by TT. The results are in agreement with those of Bierman et al. (2004) in a study on the association of leptin genotypes with fat and muscle traits in crosses of Angus x Hereford, Simmental x Hereford, and Tarentaise x Hereford. They reported that two copies of the $\mathrm{T}$ allele (cystine) produced carcasses with marbling scores of about 20 units higher, on average, than individuals with zero copies

\section{Conclusion}

The value of the leptin gene and its polymorphisms has been elucidated for the first time in Baggara cattle. This will allow for the use of molecular information in future selection of beef cattle. Further research in other regions of the sequence of this gene and other candidate genes affecting meat quality traits is called for. More SNPs should be screened in Sudanese Baggara cattle to reveal the genetic profile of such an important breed in the beef industries of the Sudan and neighboring African countries using high throughput techniques.

Authors' Contributions. RMAO laboratory work, genotyping, data analysis and wrote the draft manuscript. MAM molecular genetics analyses. LMAM analyzed the data. IAN meat analysis. MT coordination, data analysis and correction and review of the draft manuscript. FME-L design of the study and reviewed the final draft. YK design and review of the draft manuscript. ADAB samples collection and laboratory work. KIZJ data analysis, genotyping process, revising the manuscript. M- 
KAA supervised, designed, corrected the draft manuscript. All authors read and approved the final manuscript.

Acknowledgments. Research funds were provided by the University of Khartoum, Sudan (2018-/2019 Research Budget). The technical support of the Department of Genetics and Animal Breeding, Faculty of Animal Production, University of Khartoum is also acknowledged. Special thanks are extended to the staff of the Centre of Excellence, Genetics and Molecular Biology laboratory at the Department of Zoology, Faculty of Science University of Khartoum, Sudan and we are also grateful to the staff of the Animal Biotechnology Laboratory, Department of Animal Production, University of Science and Technology, Jordan.

Competing Interests. The authors declare that they have no competing interests.

\section{References}

1. Alsiddig, M. A., Babiker, S. A., Galal, M. Y. and Mohammed, A. M. (2010). Phenotypic characterization of Sudan Zebu cattle (Baggara Type). Res J Anim Vet Sci, 5:48-52.

2. AOAC (2016). Official Methods of Analysis (20th edition). Association of Official Analytical Chemists (AOAC). AOAC International Suite 3002275 Research Blvd Rockville, Maryland 20850-3250, USA.

3. Awan, F. M., Obaid A., Ikram, A. and Janjua, H. A. (2017). Mutation-Structure-Function Relationship Based Integrated Strategy Reveals the Potential Impact of Deleterious Missense Mutations in Autophagy Related Proteins on Hepatocellular Carcinoma (HCC): A Comprehensive Informatics Approach. Int. J. Mol. Sci., 18: 139. doi:10.3390/ijms18010139

4. Bierman, C. D., Marshall, D. M., Campbell, E. and Granholm, N. H. (2004). Associations of a Leptin gene polymorphism with beef carcass traits. South Dakota State University, SDSU Beef Report, 2003-2004, Brookings, SD.

5. Biscarini, F, Nicolazzi, E. L., Stella, A., Boettcher, P. J. and Gandini, G. (2015). Challenges and opportunities in genetic improvement of local livestock breeds. Front. Genet., 6:33. doi: 10.3389/fgene.2015.00033

6. Bouton, P. E., Harris, P. E., Shorthose, W. R. and Ellis, R. W. (1978). Comparison of some properties of meat from normal steers and steers heterozygous for muscular hypertrophy. Meat Science, 2:161-167.

7. Choudhary, V., Kumar, P., Bhattacharya, T. K., Bhushan, B. and Sharma, A. (2005). DNA polymorphism of leptin gene in Bos indicus and Bos taurus cattle. Genetics and Molecular Biology, 28, 4: 740-742.

8. da Silva, R. C. G., Ferraz, J. B. S., Meirelles, F. V., Eler, J. P., Balieiro, J. C. C., Cucco, D. C., Mattos, E. C., Rezende, F. M. and Silva, S. L. (2012). Association of single nucleotide polymorphisms in the bovine leptin and leptin receptor genes with growth and ultrasound carcass traits in Nellore cattle. Genetics and Molecular Research, 11(4): 3721-3728.

9. Falconer, D. S. and Mackay, T. F. C. (1996). Introduction to quantitative genetics. 4th ed. Longman, Essex, UK.

10. Fergusson, D. M. (2004). Objective on-line assessment of marbling: A brief review. Aust J of Exp Agric, 44, 681685. DOI: $10.1071 / \mathrm{EA} 02161$

11. Fiona, C., Buchanan, A., Fitzsimmons, C. J., Andrew, G., VanKessel, A., Tracey, D., Winkelman-Sim, T. D. C. and Schmutz, S. M. (2002). Association of a missense mutation in the bovine leptin gene with carcass fat content and leptin mRNA levels. Genet. Sel. Evol., 34: 105-116.

12. Geary, T. W., McFadin, E. L., MacNeil, M. D., Gringe, E. E., Short, R. E., Funston, R. N. and Keisler, D. H. (2003). Leptin as a predictor of carcass composition in beef cattle. J. Anim. Sci., 81(1):1-8. https://doi.org/10.2527/2003.8111

13. Harris, R. B. S. (2014). Direct and indirect effects of Leptin on adipocyte metabolism. Biochim Biophys Acta. 1842(3): 414-423. doi: 10.1016/j.bbadis.2013.05.009.

14. Hopkins, D. L., Littlefield, P. J. and Thompson, J. M. A. (2000). A research note on factors affecting the determination of myofibrillar fragmentation. Meat Sci., 56:19-22. DOI: 10.1016/s0309-1740(00)00012-7

15. Kaur, P. K., Tripathi, N., Desale, J., Neelagiri, S., Yadav, S., Bharatam P. V., and Singh, S. (2016). Mutational and Structural Analysis of Conserved Residues in Ribose5-Phosphate Isomerase B from Leishmania donovani: Role in Substrate Recognition and Conformational Stability. PLoS ONE 11(3): e0150764

16. Koopaee, H. and Koshkoiyeh, A. E. (2014). SNPs genotyping technologies and their applications in farm animals 
breeding programs: Review. Brazilian Archives of Biology and Technology [online]. 57 (1): 87-95.

17. MacDougald, O. A., Hwang, C-S., Fan, H. and Lane, M. D. (1995). Regulated expression of the obese gene product (leptin) in white adipose tissue and 3T3-L1 adipocytes. Proc. Natl. Acad. Sci. (USA), 92: 9034-9037

18. Meyers, L. S., Gamst, G. and Guarino, A. J. (2009). Data Analysis Using SAS Enterprise Guide. Cambridge University Press. www.cambreidge.org/9780521130073

19. Miller, S. P. (2010). Genetic improvement of beef cattle through opportunities in genomics. R. Bras. Zootec. [online]. 39, 247-255. DOI: 10.1590/S1516-35982010001300027

20. Miller, S. A., Dykes, D. D. and Polesky, H. F. (1988). A simple salting out procedure for extracting DNA from human nucleated cells. Nucleic Acids Res, 16: 12-15. doi: 10.1093/nar/16.3.1215

21. Mohamed, S. E. I., Ahmed, R. M., Jawasreh, K. I. Z., Salih, M. A. M., Abdelhalim, D. M., Abdelgadir, A. W., Obeidat, Md. T., Musa, L. M. A. and Ahmed, M-K. A. (2020). Genetic polymorphisms of fecundity genes in Watish Sudanese desert sheep. Veterinary World, 13(4): 614-621.

22. Mrode, R., Ojango, J. M. K., Okeyo, A. M. and Mwacharo, J. M. (2019). Genomic selection and use of molecular tools in breeding programs for indigenous and crossbred cattle in developing countries: Current status and future prospects. Front. Genet. 9:694. doi: 10.3389/fgene.2018.00694

23. Nkrumah, J. D., Li, C., Yu, J. and Hansen, C. (2005). Polymorphisms in the bovine leptin promoter associated with serum leptin concentration, growth, feed intake, feeding behavior, and measures of carcass merit. J Anim Sci, 83: 20-28. doi:10.2527/2005.83120x

24. Omer, R. M. A., Masri, M. A. R. M., Jawasreh, K. I., Nour, I. A., Biraima, A. D. A., Musa, L. M. A. and Ahmed, M-K. A. (2018). Molecular detection of selected genetic polymorphisms in growth hormone and Insulin like growth factor 1 genes in indigenous Sudanese Baggara Cattle. Kafkas Univ Vet Fak Derg, 24 (2): 187-194. DOI: $10.9775 / \mathrm{kvfd} .2017 .18556$

25. Ramos-Lobo, A. M. and Donato Jr., J. (2017). Comprehensive review. The role of leptin in health and disease. Temperature, 4 (3): 258-291. https://doi.org/10.1080/23328940.2017.1327003

26. Shafey, H. I., Mahrous, K. F., Hassan, A. A. M., Rushdi, H-E. and Ibrahim, M. A. M. (2020). Single-nucleotide polymorphisms in FABP4 gene associated with growth traits in Egyptian sheep. Veterinary World, 13(6): 11261132. doi: www.doi.org/10.14202/vetworld.2020.1126-1132

27. Shin, S. C. and Chung, E. R. (2007). Association of SNP marker in the Leptin gene with carcass and meat quality traits in Korean cattle. Asian-Australasian J Anim Sci, 20(1). DOI: 10.5713/ajas.2007.1

28. Souza, F. R., Mercadante, M. E., Fonseca, L. F. and Ferreira, L. M. (2014). Assessment of DGAT1 and LEP gene polymorphisms in three Nelore (Bos indicus) lines selected for growth and their relationship with growth and carcass traits. J Anim Sci, 88: 435-441. doi:10.2527/jas.2009-2174.

29. Tajima, F. and Nei, M. (1984). Estimation of evolutionary distance between nucleotide sequences. Mol Biol Evol, 1: 269-285. DOI: 10.1093/oxfordjournals.molbev.a040317.

30. Tamura, K., Stecher, G., Peterson, D., Filipski, A. and Kumar, S. (2013). MEGA6 molecular evolutionary genetics analysis version 6.0. Mol Biol Evol, 30 (12): 2725-2729. DOI: 10.1093/molbev/mst197.

31. Tartaglia, L. A. (1997). The leptin receptor. J Biol Chem, 272: 6093-6096, doi: 10.1074/jbc.272.10.6093.

32. Venselaar, H., Te Beek, T. A., Kuipers, R. K., Hekkelman, M. L. and Vriend, G. (2010). Protein structure analysis of mutations causing inheritable diseases. An e-Science approach with life scientist friendly interfaces. BMC Bioinformatics, 8;11:548. doi: 10.1186/1471-2105-11-548. PMID: 21059217; PMCID: PMC2992548.

33. Warner, R. (2014). Measurement of Meat Quality: Measurements of Water-holding Capacity and Color Objective and Subjective. In: Carrick Devine \& Michael Dikeman, editors-in-chief. Encyclopedia of Meat Sciences 2e, Vol. 2, Oxford: Elsevier; 2014. pp. 164-171

34. Wilson, R. T. (2018). Livestock in the Republic of the Sudan: Policies, production, problems, and possibilities. Anim. Husb. Dairy Vet Sci, 2(3): 1-12.

35. Woronuk, G. N., Marquess, F. L., James, S. T., Palmer, J., Berryere, H., Deobald, T., Howie, S. and Kononoff, P. J. (2012). Association of leptin genotypes with beef cattle characteristics, Anim Genet., 43(5):608-610. doi: 10.1111/j.1365-2052.2012.02320.x.

36. Zhang, Y., Proenca, R., Maffei, M. and Barone, M. (1994). Positional cloning of the mouse obese gene and its human homologue. Nature, 372: 425-432. DOI:10.1038/372425a0 